\title{
Giving Voice to the Voiceless During the COVID-19 Pandemic
}

\author{
Israel Júnior Borges do Nascimento ${ }^{1,2 *}$, Santino Filoso ${ }^{3}$ and Milena Soriano Marcolino ${ }^{1}$ \\ ${ }^{1}$ University Hospital and School of Medicine, Universidade Federal de Minas Gerais, Brazil
}

${ }^{2}$ Medical College of Wisconsin, United States of America

${ }^{3}$ Yorkville University, Canada

*Corresponding author: Israel Júnior Borges do Nascimento, Avenida Professor Alfredo Balena, 110 - $1^{\circ}$ Andar - Ala Sul - Sala 107

- Belo Horizonte, Minas Gerais, Brazil

\begin{tabular}{|c|c|}
\hline ARTICLE INFO & ABSTRACT \\
\hline Received: 慧 April 04, 2020 & Citation: Israel Júnior Borges do Nascimento, Santino Filoso, Milena Soriano Marcolino. \\
\hline Published: 幽 April 13, 2020 & $\begin{array}{l}\text { Giving Voice to the Voiceless During the COVID-19 Pandemic. Biomed J Sci \& Tech Res } \\
\text { 27(1)-2020. BJSTR. MS.ID.004435. }\end{array}$ \\
\hline
\end{tabular}

\section{Editorial}

Since the discovery of the Severe Acute Respiratory Syndrome Coronavirus 2 (SARS-CoV-2), the causative agent for COVID-19, almost a million cases and more than 70.000 deaths have been reported in affected countries.1 It is well-known that people with underlying diseases are at higher risk for severe disease and death. However, no study has yet assessed the impact of COVID-19 among vulnerable populations, such as homeless people and people living in tough neighborhoods. Homeless individuals who live on the street are at particular risk during a pandemic, given that many sleep without a roof over their heads, have little to no money, sporadic (at best) contact with their families, no employment and often low levels of education. 2 Perhaps most distressing of all, a majority lack access to regular healthcare. Those factors, compounded with a potential lack of awareness of current world issues, put a city's homeless population at a much higher level of risk than other social classes [1-3].

As scientific research has repeatedly proven, marginalized populations carry a higher risk of contracting respiratory infections, influenza-like illnesses and have an elevated prevalence of human immunodeficiency virus infection (HIV) and other sexually transmitted diseases (such as syphilis, hepatitis). 3 Consider Brazil, with its estimated homeless population of 101,854 spread out across the country (this figure excludes everyone who lives in a favela, because although those neighborhoods are full of people from lower socio-economic classes, they still have a roof over their heads). 4 It is logical to deduce that homeless people in Brazil are at an increased risk of being infected by COVID-19, due to a lack of basic hygiene, access to public health care and perhaps, accurate and up-to-date information surrounding the pandemic. In order to ensure that current information about COVID-19 is democratically available to all members of a society, politicians need to consider adopting integrative and prophylactic measures [4-6]. Public institutions and decision-makers must consider taking concrete measures to inform homeless people about the pandemic and work to offset their odds of becoming infected. As some of the most vulnerable individuals in a city, homeless people run the risk of falling through the cracks and being overlooked. Health interventions such as assertive educational and community social projects and by extension, a vaccination program when available would go a long way towards lowering the risk of an outbreak amongst the homeless population [7].

In less advantaged or socially homogenous societies where the virus has disseminated, government decisions have potentially favor wealthy classes, which are proven to be at lower risk of contamination of infectious diseases. 5 For instance, the Brazilian Government has proposed a decree that makes relations between employers and employees more flexible, which allows working hours and wages to be reduced by up 50\% during the COVID-19 pandemic. 6 While these decisions do not dramatically affect the 
middle- or high-class society strata, they will dramatically and adversely influence the day-to-day lives of the low-income families (families that earn less than 2 minimum salaries, approximately $\$ 370 /$ month). These poorer families will simply not have enough financial resources to concomitantly afford rental expenses, food, electricity, water and even basic hygiene needs. The primary consequence of the beforementioned actions is a higher infection rate among low-income employees as they frequently perform manual work which is incompatible with a home-office pattern. Furthermore, these workers are often more likely to go to work when they are sick as they are often not covered by sick leave policies.

Additional consequences of these governmental actions are likely to be psychological stress and mental illness, due to the duality of maintenance of basic life needs and the exposure to the contamination risk as well as lower access to health care, which tend to be public based, frequently crowded and with limited professional resources. In India, where more than two-thirds of the population live in poverty and the second most populated country in the world, the situation could be even worse. Even washing hands with clean water and soap can be challenging and difficult to do. In this context, people suffering poverty circumstances are very likely to be associated with higher risk levels of contamination and a deadlier infection. Another noteworthy example of the impact of novel coronavirus on human life can be also observed in the United States of America, where more than 27 million people do not have health insurance whatsoever and theoretically would not receive prompt medical care once infected with the coronavirus. 7 Nevertheless, the American government wisely invoked the Stafford Act for this global sanitary emergency, giving access to the National fund in a trial to mitigate the impacts of the infection.

ISSN: 2574-1241

DOI: $10.26717 /$ BJSTR.2020.27.004435

Israel Júnior Borges do Nascimento . Biomed J Sci \& Tech Res

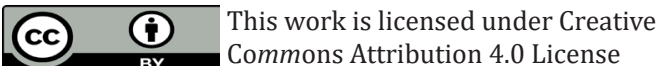

Submission Link: https://biomedres.us/submit-manuscript.php
Indeed, poor and marginalized communities are likely to be at higher risk of COVID-19 infection and complications. The international focus now should be on measures to minimize transversal contamination (preventive methods based on strong scientific evidence) and to adequately treat infected patients. Not only it is the morally responsible thing to do as active members of our community, but it will also, by default, reduce the transmissibility, spread and infection rate of COVID-19.

\section{Acknowledgement}

None

\section{Conflict of Interest}

No conflict of interest.

\section{References}

1. (2020) John Hopkins University. Coronavirus COVID-19 Global Cases by the Center for Systems Science and Engineering (CSSE) at John Hopkins University (JHU).

2. Rimawi BH, Mirdamadi M, John JF Jr (2014) Infections and Homelessness: Risks of Increased Infectious Diseases in Displaced Women. World Medical \& Health Policy 6: 118-132.

3. Wingley A, Dawson A (2016) Vulnerability and Marginalized Populations. In: Public Health Ethics Analysis. Springer International Publishing 203240.

4. Natalino MAC. Estimativa da população em situação de rua no Brasil. Instituto de Pesquisa Econômica Aplcada.

5. Quinn SC, Kumar S (2014) Health Inequalities and Infectious Disease Epidemics: A Challenge for Global Health Security. Biosecurity and Bioterrorism: Biodefense Strategy, Practice, and Science 12: 263-273.

6. VEJA. [Governo vai permitir a redução de jornada e de salário pela metade].

7. (2018) United States Census Bureau. Health insurance coverage in the United States.

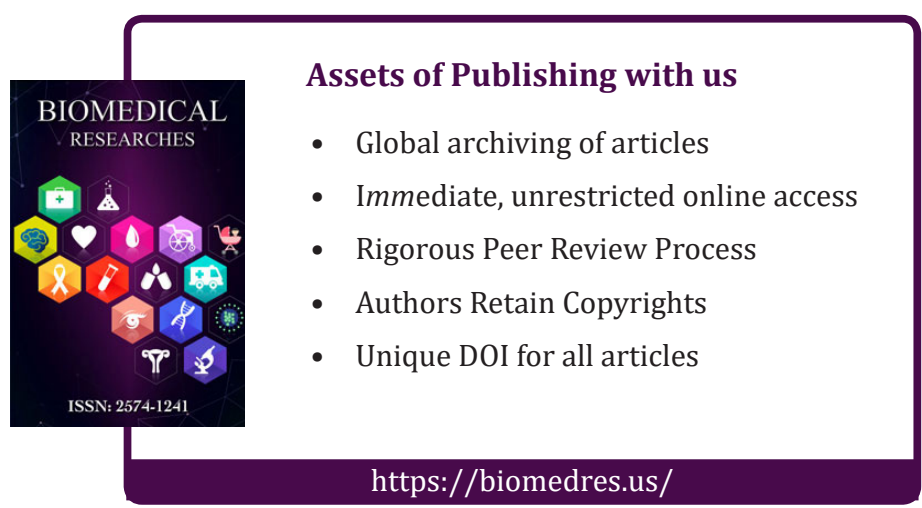

